\title{
Towards Sustainable Organic Farming Systems
}

\section{Daniel El Chami}

Timac Agro Italia S.p.A., S.P.13, Località Ca' Nova, 26010 Ripalta Arpina CR, Italy; daniel.elchami@roullier.com; Tel.: +39-0373-669-233; Fax: +39-0373-669-291

Received: 17 October 2020; Accepted: 22 November 2020; Published: 24 November 2020

check for updates

\begin{abstract}
The European Union green deal has proposed the "organic farming action plan" to render a farming system that is more sustainable and adaptable in terms of climate change mitigation and thus enable meeting the United Nations Sustainable Development Goals (UN-SDGs). While this policy instrument is fundamental to achieving sustainable agriculture, there is still no agreement on what sustainable agriculture is and how to measure it. This opinion paper proposes an ecosystem-based framework for the crop life cycle to determine the balance between the economic, social, and environmental pillars of sustainability toward supporting decision-making.
\end{abstract}

Keywords: organic farming; sustainable agriculture; ecosystem services; life cycle assessment; EU Green Deal

\section{Introduction}

Today, the emergent and consolidated quantitative literature concerning organic farming is attempting to overcome challenges of (i) its environmental ineffectiveness [1,2]; (ii) its socioeconomic inefficiency [3]; and (iii) disputed ethical correctness that can vary from the consumer's side to the producer's side depending on the case study and subject [4]. Advocates of this practice-as a holistic practice that shores up the interrelationship between farm biota, its production, and the overall environment—are increasingly being criticised regarding its agricultural sustainability.

The "organic farming action plan", proposed by the European Commission under the EU Green Deal (https://ec.europa.eu/info/strategy/priorities-2019-2024/european-green-deal_en) for the development of European organic production, is an ambitious proposal to transform organic farming to a more sustainable farming practice that respects the balance between the three central pillars of sustainable development: economy, society, and environment. According to this plan, reaching the objectives will be possible through investment and innovation in sustainable farming.

Policy intervention toward achieving sustainability in organic agriculture, that has been requested by Eyhorn et al. [5], is fundamental. I agree with the authors, and share with the commission the concern and determination to transform organic farming into a sustainable practice, to further (i) improve the wellbeing of farmers; (ii) reduce environmental burdens; and (iii) increase market supply to ensure a fair market price (Pareto optimal) and make organic products available for all and not only "food for the rich."

However, policy instruments need the correct tools and methods for implementation and evaluation and, to date, there is no agreement on what sustainable agriculture is and how it may be quantified [6]. How can "raising legal requirements and industry norms" or "supporting organic systems to improve their performances" for more sustainable products, as suggested by Eyhorn et al. [5], be possible in the absence of tools to quantify the sustainability of a product?

The following paragraphs will describe two cases of nutritional elements banned in organic farming, whose use under certain conditions could improve the performance of organic systems and reduce pressure on resources. Based on this knowledge, a conceptual framework is proposed for quantifying, through a scientific and consolidated method, the sustainability of organic farming. 


\section{Phosphorus Use}

According to the scientific literature and the European Sustainable Phosphorus Platform (ESPP), phosphorus $(\mathrm{P})$ is essential for food security and agriculture. Still, it is a non-renewable resource, and phosphorus reserves are being depleted [7]. At the same time, phosphorus loss poses major environmental issues; its use in agriculture as a fertiliser is the principal contributor to eutrophication and surface water quality deterioration [8].

Sustainable management of phosphorus reserves is the key to tackling these issues. Hence, sustainable management should not be exclusively associated with environmental pollution, and transdisciplinary processes are required such that fundamental factors such as food security, resource depletion, governance, and innovation can be included $[9,10]$.

Phosphate rock, in its natural state, is allowed in organic farming. However, in this state, phosphorus is not available to the crop, and the quantities required for application would completely participate in eutrophication. Ditta et al. [11] suggest organic matter and phosphate-solubilising microorganisms (PSMs) be incorporated to increase the P content in crops to between $4.3 \%$ and $12.9 \%$, which still amounts to a significant loss of phosphorus into natural ecosystems. Yet, studies in the field have demonstrated that superphosphate (a soluble $\mathrm{P}$ form obtained by acidifying rock phosphates with sulfuric or phosphoric acid), at the same level of $\mathrm{P}$ fertilisation, has a higher P-use efficiency than the natural rock phosphate [12-14], with variable efficiency levels depending on soil acidity. Furthermore, organically complexed superphosphate (CSP) is a new type of phosphate that has demonstrated potential to significantly inhibit phosphorus fixation in soils, increasing its efficiency in different soil types with diverse physicochemical features $[15,16]$. However, these efficient forms of phosphorus are banned in organic farming.

\section{Calcium Use}

Calcium (Ca) is an essential plant nutrient, crucial for all crops at different concentrations depending on the species variety, type of soil type and application, and timing. Despite the abundance of calcium in soils, some plant varieties (calcicole species) which require high concentrations of intracellular calcium compared to other calcifuge crops could suffer from a range of calcium-deficiency disorders that affect tissues or organs that are naturally low in calcium [17]. These include the bitter pit of apple; the blossom end rot (BER) of watermelon, pepper, and tomato; internal rust spot in potato tubers and carrot roots, tipburn in lettuce and strawberry, blackheart of celery, internal browning of Brussels sprout, and internal browning of pineapple. The FAO [18] has reported that food losses occur mostly at production and post-harvest levels and accounts for $47 \%$ of the total food wastage in Europe. Calcium-related deficiencies on calcicole crops (e.g., leafy vegetables, Solanaceae vegetables, apple, and strawberry) could generate up to $50 \%$ of the yield losses [19]. Therefore, application timing and the type of calcium are crucial to overcoming this physiological barrier and reducing food losses generated from calcium-related deficiencies.

According to the literature, the ionic exchange of calcium at the physiological level is responsible for this deficiency, excluding any physical calcium deficiency in soils. For this reason, symptoms are observed, according to White and Broadley [20], (a) in young expanding leaves, e.g., in the tipburn of leafy vegetables; (b) enclosed tissues, e.g., in brown heart of green vegetables or blackheart of celery; or (c) in tissues fed principally by the phloem rather than the xylem, e.g., in blossom end rot of watermelon, pepper, and tomato, bitter pit of apple, and the empty pods of peanut.

Application timing and the type of calcium, according to the literature, improve yield quality and increase product shelflife. Indeed, Karp and Starast [21] explored the impacts of calcium foliar applications during the flowering stage of strawberry and showed that foliar calcium fertilisation during flowering could, if accompanied by adequate mulching practice, increase the yield of first-grade fruits and reduce spoiled fruits. Furthermore, Herath et al. [22] recommended, in addition to basal lime application on pineapples, administering a calcium application six months after plantation (during the flowering stage) to improve the post-harvest quality and the product shelflife. Moreover, 
Zozo et al. [23] showed that application of both calcium and boron sprays (the first at tillering and the second at early bloom) improves growth, flower fertilisation, and the number of fertile tillers of wheat plants, resulting in higher grain yield.

The organic sources of calcium used for plant nutrition that were retrieved from the literature were homemade recipes that cannot be scaled up for use at a farm, e.g., dissolved eggshells (a recipe that requires a month of preparation and that yields approximately six litres of final spray mix using 20 eggs) and chamomile infused in boiled water at a ratio of 1:4. Alternatively, other sources of calcium in plant nutrition could be mined lime, gypsum, and/or other chemical compounds such as calcium chloride or calcium carbonate. The European Commission once consented, under specific conditions, to the use of foliar treatment with calcium chloride in the organic production of apple trees after the identification of a deficit [24](Annex I). This consent was reversed without any scientific explanation.

\section{Conceptual Framework}

Thus, would using pure phosphate rock in high quantities for organic agriculture be more sustainable than using fewer amounts of superphosphate with higher use efficiency and under specific conditions (e.g., alkaline soils)? Or would using calcium to avoid food waste under certain growing circumstances be less sustainable than banning its use in organic practice?

To answer similar questions and to support decision-making, we need to assess the sustainability of agro-systems using scientific evidence. The framework suggested in Figure 1 is an evolution of different research recommendations [6,25]; it integrates an ecosystem-based approach and life-cycle analysis (LCA) for multi-criteria decision-making to provide an adequate tool for assessment of the trade-offs between generated or lost ecosystem services in sustainable agriculture. This framework can be used to determine nutrition inputs for organic farming and in other agro-systems such as conservation agriculture, biodynamic agriculture, and conventional agriculture.

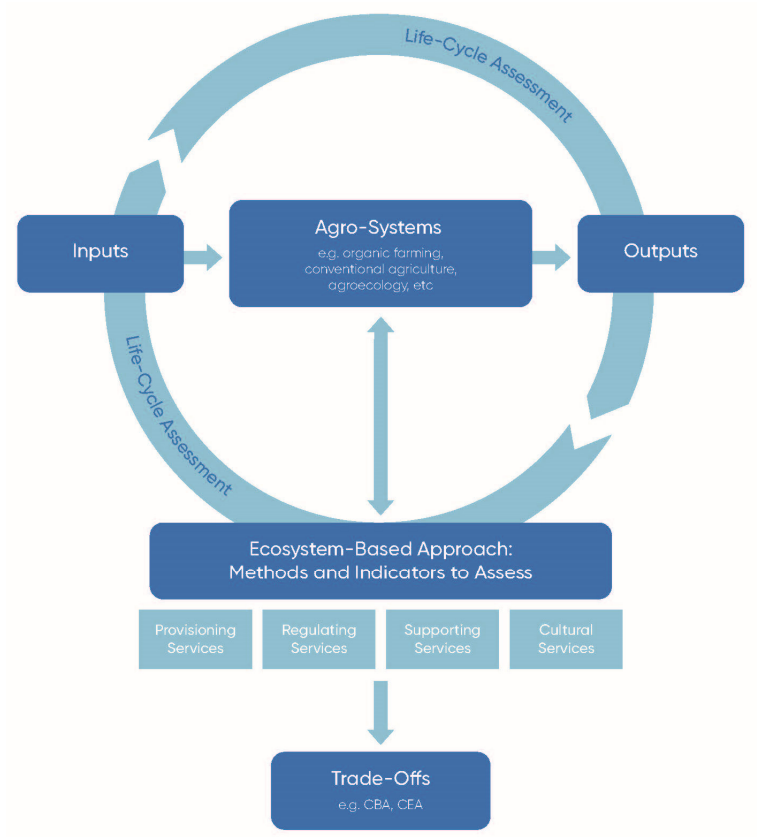

Figure 1. The conceptual framework suggested for sustainable agriculture assessment and evaluation.

LCA is a consolidated methodology abundantly applied to agricultural systems. Currently, this assessment method is undertaking continuous evolution to integrate social impact assessment with sustainability assessment in the so-called Social Life Cycle Assessment (SLCA) and Life Cycle Sustainability Assessment (LCSA) [26,27]. Some attempts have been made, and the ecosystem-based approach is only modestly used in agriculture [28,29]. Its integration into agriculture requires the selection of ecosystem services divided into four major groups: i) regulating services (e.g., pollination, 
climate, and water regulation); ii) provisioning services (e.g., food and fibre); iii) supporting services (e.g., primary production and nutrient cycling); and iv) cultural services (e.g., science and education, and inspiration). It is essential to identify methods and indicators for the assessment of these ecosystem services.

Currently, methods for valuing ecosystem services are becoming more effective and more available [30]. It is crucial to select consolidated and versatile methods and indicators to cover all agro-systems regardless of the crop, practice, and soil and climate conditions. Once assessed, a cost-benefit analysis (CBA) or a cost-effectiveness analysis (CEA) would determine the trade-offs between different services.

This framework is the only scientific method foreseen to rigorously integrate sustainable thinking into organic farming or any other farming practice. However, this requires a complete review of the list of inputs approved by the European Union with respect to all the fundamental principles upon which organic production is based: (i) prohibition of the use of genetically modified organisms, (ii) forbidding the use of ionising radiation; (iii) limiting the use of artificial fertilisers, herbicides, and pesticides; and (iv) prohibiting the use of hormones and antibiotics except when necessary for animal health.

Funding: This research received no external funding.

Acknowledgments: The author would like to acknowledge the support of Valentina Pisati, who participated in the graphical conception of Figure 1.

Conflicts of Interest: The authors declare that there is no conflict of interest.

\section{References}

1. Searchinger, T.D.; Wirsenius, S.; Beringer, T.; Dumas, P. Assessing the efficiency of changes in land use for mitigating climate change. Nature 2018, 564, 249. [CrossRef] [PubMed]

2. Leifeld, J. How sustainable is organic farming? Agr. Ecosyst. Environ. 2012, 150, 121-122. [CrossRef]

3. Qiao, Y.; Halberg, N.; Vaheesan, S.; Scott, S. Assessing the social and economic benefits of organic and fair trade tea production for small-scale farmers in Asia: A comparative case study of China and Sri Lanka. Renew. Agr. Food Syst. 2016, 31, 246-257. [CrossRef]

4. Padel, S.; Nicholas, P.; Jasinska, A.; Lampkin, N. Ethical concerns associated with organic food in Europe. In Proceedings of the 16th IFOAM Organic World Congress (OWC), Modena, Italy, 16-20 June 2008.

5. Eyhorn, F.; Muller, A.; Reganold, J.P.; Frison, E.; Herren, H.R.; Mueller, A.; Sanders, J.; El-Hage Scialabba, N.; Seufert, V.; Smith, P.; et al. Sustainability in global agriculture driven by organic farming. Nat. Sustain. 2019, 2, 253-255. [CrossRef]

6. El Chami, D.; Daccache, A.; El Moujabber, M. How can sustainable agriculture increase climate resilience? A systematic review. Sustainability 2020, 12, 3119. [CrossRef]

7. Daneshgar, S.; Callegari, A.; Capodaglio, A.G.; Vaccari, D. The Potential Phosphorus Crisis: Resource Conservation and Possible Escape Technologies: A Review. Resources 2018, 7, 37. [CrossRef]

8. Carpenter, S.R. Eutrophication of aquatic ecosystems: Bistability and soil phosphorus. Proc. Natl. Acad. Sci. USA 2005, 102, 10002-10005. [CrossRef] [PubMed]

9. Scholz, R.W.; Ulrich, A.E.; Eilittä, M.; Roy, A. Sustainable use of Phosphorus: A finite resource. Sci. Total Environ. 2013, 461-462, 799-803. [CrossRef] [PubMed]

10. Schröder, J.J.; Cordell, D.; Smit, A.L.; Rosemarin, A. Sustainable Use of Phosphorus: EU Tender Env.B.1./ETU/2009/0025. Plant Research International. 2010. Available online: https://library.wur.nl/ WebQuery/wurpubs/reports/404463 (accessed on 20 November 2020).

11. Ditta, A.; Muhammad, J.; Imtiaz, M.; Mehmood, S.; Qian, Z.; Tu, S. Application of rock phosphate enriched composts increases nodulation, growth and yield of chickpea. Int. J. Recycl. Org. Waste Agricult. 2018, 7, 33-40. [CrossRef]

12. Lukiwati, D.R. Effect of rock phosphate and superphosphate fertiliser on the productivity of maise var. Bisma. In Food Security in Nutrient-Stressed Environments: Exploiting Plants' Genetic Capabilities; Developments in Plant and Soil Sciences, vol 95; Adu-Gyamfi, J.J., Ed.; Springer: Berlin/Heidelberg, Germany, 2002; pp. 183-187. [CrossRef] 
13. Mallarino, A.P.; Rueber, D. Evaluation of Superphosphate and Rock Phosphate for a Corn-Oat-Forage Rotation. In Northern Research and Demonstration Farm, Annual Progress Reports, ISRF97-22; Iowa State University: Ames, IA, USA, 1997; pp. 6-8.

14. Choudhary, M.; Peck, T.R.; Paul, L.E.; Bailey, L.D. Long-term comparison of rock phosphate with superphosphate on crop yield in two cereal-legume rotations. Can. J. Plant Sci. 1994, 74, 303-310. [CrossRef]

15. Giovannini, C.; Garcia-Mina, J.M.; Ciavatta, C.; Marzadori, C. Effect of organic-complexed superphosphates on microbial biomass and microbial activity of soil. Biol. Fertil Soils 2013, 49, 395-401. [CrossRef]

16. Erro, J.; Urrutia, O.; Baigorri, R.; Aparicio-Tejo, P.; Irigoyen, I.; Torino, F.; Mandado, M.; Yvin, J.C.; Garcia-Mina, J.M. Organic complexed superphosphates (CSP): Physicochemical characterisation and agronomical properties. J. Agric. Food Chem. 2012, 60, 2008-2017. [CrossRef] [PubMed]

17. Pilbeam, D.J.; Morley, P.S. Chapter 5-Calcium. In Handbook of Plant Nutrition; Barker, A.V., Pilbeam, D.J., Eds.; CRC Press: Cleveland, OH, USA, 2007; pp. 121-144.

18. FAO. Food Wastage Footprint, Impacts on Natural Resources-Summary Report; Food and Agriculture Organization of the United Nations (FAO): Rome, Italy, 2013; 61p.

19. Taylor, M.D.; Locascio, S.J. Blossom-End Rot: A Calcium Deficiency. J. Plant Nutr. 2004, 27, $123-139$. [CrossRef]

20. White, P.J.; Broadley, M.R. Calcium in Plants. Ann. Bot. 2003, 92, 487-511. [CrossRef] [PubMed]

21. Karp, K.; Starast, M. Effects of springtime foliar fertilisation on strawberry yield in Estonia. Acta Hortic. 2002, 594, 501-505. [CrossRef]

22. Herath, H.M.I.; Bandara, D.C.; Abeysinghe Banda, D.M.G. Effect of pre-harvest calcium fertiliser application on the control of internal browning development during the cold storage of pineapple 'Mauritius' (Ananas comosus (L.) Merr.). J. Hort. Sci. Biotech. 2003, 78, 762-767. [CrossRef]

23. Zoz, T.T.; Steiner, F.; Seidel, E.P.; Castagnara, D.D.; de Souza, G.E. Foliar application of calcium and boron improves the spike fertility and yield of wheat. Biosci. J. 2016, 32, 873-880. [CrossRef]

24. EC. Laying Down Detailed Rules for the Implementation of Council Regulation (EC) No 834/2007 on Organic Production and Labelling of Organic Products with Regard to Organic Production, Labelling and Control. In Commission Regulation (EC) No 889/2008; EC: Brussels, Belgium, 2008.

25. El Chami, D.; Daccache, A. Assessing sustainability of winter wheat production under climate change scenarios in a humid climate-An integrated modelling framework. Agr. Syst. 2015, 140, 19-25. [CrossRef]

26. Jørgensen, A.; Le Bocq, A.; Nazarkina, L.; Hauschild, M. Methodologies for social life cycle assessment. Int. J. Life Cycle Assess. 2008, 13, 96-102. [CrossRef]

27. Finkbeiner, M.; Schau, E.M.; Lehmann, A.; Traverso, M. Towards life cycle sustainability assessment. Sustainability 2010, 2, 3309-3322. [CrossRef]

28. Gasparatos, A.; Romeu-Dalmau, C.; von Maltitz, G.P.; Johnson, F.X.; Shackleton, C.; Jarzebski, M.P.; Jumbe, C.; Ochieng, C.; Mudombi, S.; Nyambane, A.; et al. Mechanisms and indicators for assessing the impact of biofuel feedstock production on ecosystem services. Biomass Bioenerg. 2018, 114, 157-173. [CrossRef]

29. Hails, R.S.; Chaplin-Kramer, R.; Bennett, E.; Robinson, B.; Daily, G.; Brauman, K.; West, P. Determining the value of ecosystem services in agriculture. In Agricultural Resilience: Perspectives from Ecology and Economics; Gardner, S., Ramsden, S., Hails, R.S., Eds.; Cambridge University Press: Cambridge, UK, 2019; pp. 60-89. [CrossRef]

30. Power, A.G. Ecosystem services and agriculture: Tradeoffs and synergies. Philos. Trans. R. Soc. B 2010, 365, 2959-2971. [CrossRef] [PubMed]

Publisher's Note: MDPI stays neutral with regard to jurisdictional claims in published maps and institutional affiliations.

(C) 2020 by the author. Licensee MDPI, Basel, Switzerland. This article is an open access article distributed under the terms and conditions of the Creative Commons Attribution (CC BY) license (http://creativecommons.org/licenses/by/4.0/). 